\title{
Development of Volleyball Smash Training Aid Media for FIK UNIMED Students
}

\author{
Abdur Rahman Daulian Hrp ${ }^{\mathbf{1}}$, Agung Sunarno ${ }^{2}$, Amir Supriadi ${ }^{\mathbf{3}}$, Indrakasih ${ }^{\mathbf{4}}$ \\ ${ }^{1,2,3,4}$ Sports Education, Universitas Negeri Medan, Indonesia \\ abdurrahmandharahap130118@gmail.com
}

\begin{abstract}
The main objective of this research is development of media for smash training aids as a volleyball learning media. This research was conducted at FIK State University of Medan in 2021. Research at FIK Unimed Medan will be carried out from February 9 to March 4, 2021. The type of research used is research development (Research and Development), a small trial sample of 6 students and a large trial of 10 students as well as media, sports and language experts. In small group trials of 3 lecturers, and large group trials of 3 lecturers, reaching $94.23 \%$ with valid criteria can be used. Sports experts of $92.5 \%$ with valid criteria can be used. The small group trial sample of 6 PKO FIK Unimed students reached $95.23 \%$ with very effective criteria, and a large group trial sample of 10 PKO FIK Unimed Medan students reaching $87.33 \%$ with a very effective rate. Then from the test of the effectiveness and efficiency of the smash aids it reached $98 \%$ with valid criteria for use and $96 \%$ with valid criteria for use. On the basis of the data obtained, the development of the Smash assistive media product was declared feasible to be developed as one of the learning media in game material volleyball.
\end{abstract}

Keywords

volleyball; tods,

learning media

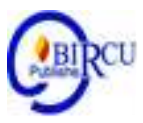

\section{Introduction}

Education institutions producing excellent and professional graduates in Physical education, coaching and Sports Science. The Faculty of Sport Sciences of Unimed has three departments, namely the department of physical education, health and recreation (PJKR), sports coaching education (PKO) and the department of sports science (IKOR). The department of health and recreation physical education has two study programs, namely: school physical education and recreational health education.

In the sports college (LPTK) various learning materials are studied according to the existing curriculum and one of them is volleyball subject. Volleyball is a team sport played by two teams, each team consisting of 6 people separated by a net. Each team has the right to play the ball up to three touches, to return it to the opponent's area. A player is not allowed to play the ball twice in a row. In order to play volleyball well, one must understand and be able to master the basic techniques available. Each player has special skills, namely as a hitter (smash), feeder (tosser), defender (libero).

Volleyball game is a sport that aims to improve physical fitness and the development of sports achievements, therefore efforts to improve and develop volleyball learning achievements need to be practiced to improve desired performance (Ferguson, 2010). Volleyball is a sport that dominates the entire community, both students and government agencies, where the development of volleyball is very rapid, this can be seen from the implementation of volleyball championships at elementary, middle, high school and general level often held. (Budiarti et al, 2019) 
Volleyball is one of the branches of soccer where you play it by dropping the ball on the opponent's field as much as possible to achieve a certain score. Another opinion says, the notion of volleyball is a sport that is played by two opposing groups where each group has six players. Between the two groups/teams the field is limited by a net barrier with a certain height. (Indrakasih et al, 2019).

Volleyball is a very fun type of game, This sport is no stranger to Indonesian society and very much played by Indonesian society from children to adults, both men and women, This is proven by the number of volleyball tournaments held at the Village, District, Regency and Provincial levels.and this volleyball game also really requires regular and directed training because the game of volleyball contains various elements of motion. The basic technique in volleyball is a process of giving birth to physical activity and proving the best possible practice to complete a definite task in volleyball.

In the game of volleyball there are several basic techniques, including techniques using the ball which include service techniques, under passing techniques, top passing techniques, smash techniques, and block techniques. To master these basic techniques requires continuous basic technique exercises and repetitions from an easy level to a complete master.

The game of volleyball originated in the United States. This game was created by a sports instructor named William G. Morgan in 1885. This game is popular with young people, but there are still some who don't know how to play it properly and correctly so that the benefits can be obtained.

The results of observations in the volleyball learning field by PKO FIK Medan State University students who did volleyball manually through games mostly failed. From the data obtained from Mrs. Dewi Endriani, a lecturer in volleyball subject for class 2019 students for two classes with a total of 67 students of the Sports Coaching Education Department, State University of Medan, still experienced a learning result that did not increase, especially when students directed the ball to be smashed into opponent's field and focus the smashed ball in a direction that cannot be reached by the opponent. With this smash aid media, it is possible that FIK UNIMED students, especially the Sports Coaching Education major, will be more effective and efficient when doing smashes.

After making observations, the results of the data were obtained: from the first question 67 students answered "YES" so the percentage was 100\%, the second question 67 students answered "YES" the percentage was $100 \%$, the third question out of 67 students who answered "YES" 50 students (75\%) and answered "NO" 17 students $25 \%$, the fourth question out of 67 students answered "YES" 4 students (6\%) and answered "NO" 63 students (96\%) and the fifth question out of 67 students who answered "YES" 51 students ( $76 \%$ ) and answered no to 16 students (24\%). From the results of observations of conditions in the field, the writer wants to develop a tool design model that provides convenience and efficiency to students. This tool is expected so that students can learn volleyball smash material effectively and efficiently. Other than that,

The needs analysis above makes it clear that many students stated that they rarely use assistive devices for volleyball smashes in learning and also many students who answered that they needed smash learning aids in learning volleyball material. 


\section{Research Methods}

This type of research is the development research or Research \& Development ( $\mathrm{R} \&$ D) of Borg \& Gall (1983: 776). This research was conducted at the Faculty of Sports Science, majoring in PKO in 2021. Volleyball subjects were randomly selected student samples, this research was limited to the eighth stage, namely product production in Research \& Development (R \& D) from Borg \& Gall. and is limited to the stage II product revision stage.

The data obtained from the analysis of the instrument, the analysis of the results of the validation of the volleyball learning media expert, the analysis of the results of the validation of the volleyball sports expert and the analysis of the results of the student response questionnaire The design of the passing over aid that will be developed can be seen in Fig 1.
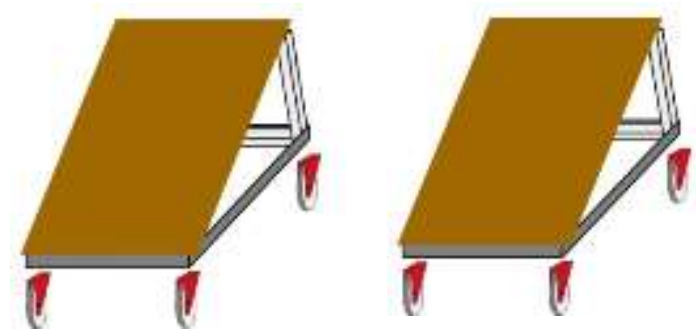

Figure 1. Tools Upper Passing Aids With Two Target Balls

\section{Results and Discussion}

This research is a type of research and development. The result of this research and development is a media product for smash training aids. There are several problems behind the development of the media for smash aids in this study. These problems include: a. The direction of the ball that is being sampled to the opponent's defensive area is not optimal $b$. Not many media for smash target aids have been used. This research and development is carried out with reference to the research and development stages according to Borg \& Gall. Borg \& Gall (1983: 775) explains that there are ten stages in research and development, but in this research and development the ten steps are simplified into eight steps.

The results of the feasibility validation analysis of the assistive media that were revised by media expert lecturers and volleyball sports experts with several aspects in each questionnaire, the percentage value of media experts was $94.23 \%$ and the percentage value of volleyball sports experts was 92.5 . \% with a decent category.

The results of the development of smash media products will then be tested in small groups to see the effectiveness of existing products. The trial of the smash assistive media product was carried out by 6 PKO students which was carried out in a specially selected FIK UNIMED field, namely some students who they did volleyball online learning in Medan. Here, researchers have limitations in being able to bring in students because there are still many students who do online learning in their respective hometowns, researchers in the field can only bring in 6 students who they do learn from Medan city. 
Table 1. Percentage (\%) of Small Group Trials

\begin{tabular}{|c|c|c|}
\hline Respondents & amount & $\mathrm{P}(\%)$ \\
\hline $\mathbf{1}$ & 12 & 80.00 \\
\hline $\mathbf{2}$ & 14 & 93.33 \\
\hline $\mathbf{3}$ & 12 & 80.00 \\
\hline $\mathbf{4}$ & 14 & 93.33 \\
\hline $\mathbf{5}$ & 14 & 93.33 \\
\hline $\mathbf{6}$ & 14 & 93.33 \\
\hline amount & $\mathbf{8 0}$ & 533.32 \\
\hline $\mathbf{P}(\boldsymbol{\%})$ & $\mathbf{9 5 . 2 3}$ & \\
\hline
\end{tabular}

The results of the development of smash media products will then be tested in large groups to see the effectiveness of existing products. The trial of the smash assistive media product was carried out by 10 PKO students who were specially selected, some of the students who had entered the volleyball course. After 10 students did the smash assistive media, then the results of their assessment were seen as follows:

Table 2. Percentage (\%) of Large Group Trials

\begin{tabular}{|c|r|r|}
\hline Respondents & \multicolumn{1}{|l|}{ amount } & $\mathrm{P}(\%)$ \\
\hline $\mathbf{1}$ & 13 & 86.66 \\
\hline $\mathbf{2}$ & 14 & 93.33 \\
\hline $\mathbf{3}$ & 14 & 93.33 \\
\hline $\mathbf{4}$ & 14 & 93.33 \\
\hline $\mathbf{5}$ & 12 & 80.00 \\
\hline $\mathbf{6}$ & 14 & 93.33 \\
\hline $\mathbf{7}$ & 12 & 80.00 \\
\hline $\mathbf{8}$ & 14 & 93.33 \\
\hline $\mathbf{9}$ & 12 & 80.00 \\
\hline $\mathbf{1 0}$ & 12 & 80.00 \\
\hline amount & $\mathbf{1 3 1}$ & 873.31 \\
\hline $\mathbf{P}(\mathbf{\%})$ & $\mathbf{8 7 . 3 3}$ & \\
\hline
\end{tabular}

Based on the results of large group trials from the results of the feasibility validation analysis of the assistive media revised by media expert lecturers and volleyball sports experts with several aspects in each questionnaire, the percentage value of media experts was obtained as $98.07 \%$ and the percentage value of volleyball sports experts is $97.5 \%$ with a decent category, The end of this research and development is the right to patent.

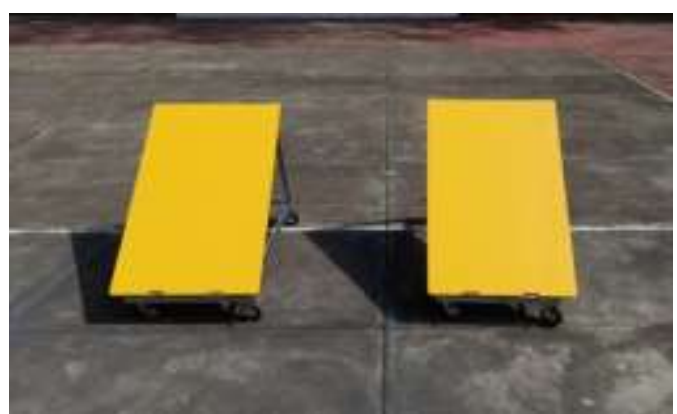

Figure 2. The final product of the Smash Training Aid Media 


\section{Conclusion}

Based on small group trials, where the value obtained is known that the empirical score obtained is $95.23 \%$ (Very Feasible) which is greater than the minimum standard value of the effective criteria so that through small group trials it can be stated that the media product for smash aids is effective as learning media in volleyball subject is quite valid.

Large group trials, where the value obtained is known that the empirical score obtained is $87.33 \%$ (Very Eligible). This means that this research is sufficient to find out the validity of the volleyball smash learning aid media for students of FIK Unimed.

Based on the data and field tests and discussion of research results, conclusions can be drawn: 1.) Producing the use of two bounce boards as a volleyball learning medium which is very useful and quality in volleyball smash learning that is feasible to use. 2.) The use of smash assistive products has a good balance, resistance and tilt as a medium or tool in volleyball smash learning, has a more effective and efficient product to be used as a volleyball smash learning medium.

\section{Suggestions and Recommendations}

Based on the existing conclusions, the suggestions put forward are as follows:

a) Volleyball smash aids help lecturing activities of FIK students, State University of Medan, especially volleyball subjects.

b) Smash aids to help learning volleyball activities.

c) To lecturers to always create creative and innovative lectures.

\section{Further Development Suggestions}

For further research, the researcher provides several suggestions to do, namely

1. For research trial subjects, it is advisable to use a broader subject, such as clubs or volleyball athletes.

2. The use of products, especially volleyball smash aids, can be linked to technology to make it even better.

\section{References}

Ahmadi, N. (2007). Guide to Volleyball Sports. Surakarta: The Era of Main Library

Arif S. Sadiman, et al. (2011). Media Education, Definition, Development, and Utilization. Jakarta: PT. Raja Grafindo Persada

Arsyad, Azhar. (2011). Learning Media. Jakarta: PT Rajagrafindo Persada

Get up, Sabaruddin Yunis. (2016). Knowledge Development for Children with Disabilities through Sports and Outbound Physical Education. Journal of Physical Education, Health and Recreation. Vol 1, No 1. Pg 70-77

Beutelstahl, Dieter. (2012). Learning to Play Volleyball. Bandung: Pionir Jaya

Beutelsthel, Dieter. (2008). Learning to Play Volleyball. Bandung: CV Pionir Jaya

Borg, Walter R. \& Gall., M. (2003). Educational research an introduction 7th edition. New York \& London: Longman

Budiarti, W. et al. (2019). Volleyball Smash Learning Model for Middle School Students. P. Budapest International Research and Critics in Linguistics and Education (BirLE) Journal. P. 239-244

Hamzah, Nina Lamatenggo. (2011). Learning Information and Communication Technology. Jakarta: Earth Literacy 
Indrakasih, et al. (2019). Development of Basic Volleyball Learning Media Based on Web Learning Materials Towards KKNI at Universitas Negeri Medan. Budapest International Research and Critics in Linguistics and Education (BirLE)Journal. 139144.

Love senses, Salman. (2018). Efforts to Improve Learning Outcomes of Passing Under the Game of Volleyball through Teaching and Training Styles for Class X Private High School Students of Darul Ilmi Murni, Deli Serdang Regency, Academic Year 2017/2018. Medan: UNIMED

Kustandi, Cecep. And Sutjipto, Bambang. (2013). Learning Media: Manual and Digital. Bogor: Ghalia Indonesia

Mutohir, Cholik. (2019). Volleyball Game. Surabaya: Graha Media

Pranopik, Muhammad. (2017). Journal of Achievement Vol. 1 No. 1, June 2017: 31-33 pISSN: 2549-9394

Sanaky. (2009). Learning Media. Yogyakarta: Safiria Insania Press

Sugiono. (2008). Quantitative research methods, qualitative and R \& D. Bandung: Alfabeta

Sugiyono. (2015). Educational Research Methods: Quantitative, Qualitative, and RND Approaches. Bandung: Alfabeta

Supriadi, Amir. (2015). The Relationship between Ankle Coordination and Skills to Seduce Football in Football Games. Journal of Sports Science. Vol 14 N0 1. 1-14

Syiroj, Akhmad. Et al. (2017). Differences in Teaching Styles and Motor Educability on Learning Outcomes of Passing Under Volleyball in Class Xi Man Rantau Prapat Students. Journal of Sports Pedagogy. Vol 3 No 1. 15-31

Viera, BL, \& Ferguson, BJ. (2004). Beginner volleyball. Jakarta: PT. Raja Grafindo Persada

Viera, Barbara L. (2004). Volleyball at Entry Level. Jakarta: Raja Grafindo Persada Publisher

Widodo, SA. (2018). Selection of Learning Media Mathematics for Junior School Students. Turkish Online Journal of Educational Technology, 17 (1), 154-160

Widodo, SA, Darhim, \& Ikhwanudin, T. (2018). Improving Mathematical Problem Solving Skills Through Visual Media Improving Mathematical Problem Solving Skills Through Visual Media. Journal of Physics: Conf. Series, 948 (1), 1-6 